\title{
AN ACOUSTIC STUDY OF PHONOLOGICAL PHRASES CONTAINING SEQUENCES OF WORDS WITH ADJACENT PRIMARY-STRESSED SYLLABLES: DOES STRESS SHIFT OCCUR IN BRAZILIAN PORTUGUESE?
}

\author{
SANDRA MADUREIRA \\ (LIAACC/ LAEL/ DEP. LINGÜÍSTICA/PUC-SP)
}

\begin{abstract}
RESUMO O objetivo deste trabalho é discutir o fenômeno de deslocamento acentual (stress shift) em português brasileiro como postulado pela Regra do Ritmo (Rhythm Rule), fundamentando-se em evidência acústica provinda sobretudo da análise de contornos de freqüência fundamental de sintagmas fonológicos contendo sequiências de palavras em condição ou não de encontro acentual (stress clash). Para o propósito da presente discussão, seis frases de três dos corpora designados para a investigação do fenômeno são considerados. Três locutores do português brasileiro foram gravados produzindo cinco repetições de cada frase. Os resultados mostram que não há diferença entre contornos de $\mathrm{f}_{0}$ das duas condições em contraste e somente uma diferença de alinhamento de pico de $\mathrm{f}_{0}$ ocorre, dependendo este do tipo de padrão acentual lexical (oxítono ou paroxítono) da segunda palavra do sintagma. Aspectos ligados a diferenças interlingüísticas são discutidos.
\end{abstract}

\section{INTRODUCTION}

Stress shift is a phenomenon related to an alternation of stress patterns triggered by the application of the Rhythm Rule as proposed by the metrical phonological framework dating back to Liberman and Prince (1977). When in the metrical grid two primary stresses are adjacent in one level of the grid, without an intervening grid mark at the level immediately below (stress clash condition), stress shift is likely to occur, that is, stress can be shifted leftward to the first primary-stressed syllable in the sequence and the result is that clash is undone. Sequences such as "thirteen men" (clash condition), which are often mentioned in the literature on stress clash, under the application of the Rhythm Rule have the primary stress in the word "thirtéen" moved to fall on the first syllable of the word in order to avoid the clash.

In search of phonetic evidence for the occurrence of the phenomenon of stress shift postulated by the Rhythm Rule, depending on language characteristics, studies investigating the main correlates of stress (duration, fundamental frequency $-\mathrm{f}_{0}$-, intensity and vowel formant patterns) are necessary. Stress shifted syllables are expected to have longer duration, more amplitude or larger $\mathrm{f}_{0}$ inflection since greater prominence is involved. Another possibility is that the second syllable in the sequence of the two adjacent primary stressed syllables (clash condition) is given less prominence, since stress has a relational property. 
Acoustic evidence of stress shift in English has been discussed in three papers of the fourth volume of the Laboratory Phonology Series (Grabe and Warren, 1995; Vogel, Bunnell and Hoskins, 1995; Shattuck-Hufnagel, 1995). English is described as a language which favors stress shift although exceptions have been pointed out in relation to different speech styles and rate (Monaghan, 1990).

Due to some non-shared language specific features, Brazilian Portuguese (henceforth BP) is considered, in this article, to differ from English in relation to the productivity of stress shift events. Apart from some very specific stylistic uses of stress shift, our hypothesis is that, perceptually, stress shift does not occur in BP. In order to verify this, both perceptual and production evaluation tasks are necessary.

The main acoustic correlation of lexical and phrasal stress in BP is duration (Massini, 1991; Barbosa, 2000). Otherwise, $\mathrm{f}_{0}$ is a correlate of phrasal and sentence accents.

In order to consider stress shift in BP, besides the study on $\mathrm{f}_{0}$ which is presented in this article, research on duration has been conducted by Barbosa (this volume). To our knowledge no other acoustic studies are available. However, secondary stress in polisyllabic words, which involves a right to left movement, has been investigated in relation to syllable duration by Gama Rossi (1998) and by Arantes and Barbosa (forthcoming) ${ }^{1}$, but no acoustic evidence of a systematic, early prominence shift was found. Her study showed duration increases towards the main stress in the prosodic group. Metrical-based phonological accounts, however, have considered stress alternation to apply in BP (Galves and Abaurre, 1996). Moraes (1998) states rhythmic alternation in BP is reported by Said Ali as early as 1895 and it involves the alternation of strong and weak stresses in the prosodic groups such as the ones we investigate in this article.

Stress shift is a phenomenon which can not be considered without taking into account the integration between intonation and rhythm features. An attempt to develop such a model of generating prosody is pursued by Barbosa (1999; 2000; this volume) who follows a dynamic approach compatible with the acoustic-articulatory model developed by Albano (1999, 2001) to account for phonetic details and morphophonemic processes in BP. Albano's model follows theoretical proposals of Articulatory Phonology by Browman and Goldstein $(1986,1989,1990)$.

\section{RESEARCH ON STRESS CLASH: SEARCH FOR ACOUSTIC AND PERCEPTUAL EVIDENCES}

Since the seminal work of Liberman and Price (1977), stress shift in English has been thoroughly investigated on both phonological and phonetic grounds and relevant data has been collected. Among these relevant data, we would like to place emphasis on

${ }^{1}$ Arantes \& Barbosa (forthcoming) analyze a corpus specifically designed to investigate secondary stress and their findings confirm Gama-Rossi's with a more controlled corpus, that is, no clear, systematic phonetic evidence for secondary stress. 
the role of the elements which researchers have investigated more recently: context dependency, inter-subject variability and acoustic cues (duration, amplitude and f0) of the syllables of stress-shifted words as pointed out researchers over the last decade.

Beckman and Edwards (1994) point out that stress shift is perceived independently of the stress patterns of the word following the shifted, phenomenon which is confirmed by Grabe and Warren (1995)

Grabe and Warren (1995) give an alternative account of stress shift based on acoustic and perceptual evidences. They point out the inadequacies of studies which analyze stress shift without considering speech production and perception issues and intonational units. The results of their experiments show there is no acoustic evidence for stress shift, but they are based on the analysis of the first syllable of the shifted word only. As far as perception is concerned both preceding and following context are considered influential. These authors argue stress shift is constrained by nuclear stress placement and is blocked if the stress falls on the nucleus of the intonation phrase.

Shattuck-Hufnagel (1988) argues that phenomena such as pitch placement, early prominence and obligatory position of nuclear pitch accent would be involved in the perception of early prominence in the word. Shattuck-Hufnagel (1994) argues stress shift can be better explained as early placement of pitch accents.

Vogel, Bunnel and Hoskins (1995) point out that the results of both phonological and phonetic descriptions of stress shift in English have provided arguments for considering the Rhythm Rule to be an optional rule whose application is affected by subject and context variability. In their study, they find strong production and perception evidences of the application of the Rhythm Rule in English.

The results of their production experiment show there is a reduction of the second rhyme of the syllable of the stress-shifted word but the first syllable, which is perceptually judged prominent in clash conditions, show no significant differences in duration, amplitudes or $\mathrm{f}_{0}$. The effects of clash on speech production were found significant.

Shattuck-Hufnagel (1995) argues in favor of the use of phonological transcription in stress shift studies to complement phonetic data since varied acoustic cues can signal the same phonological event: pitch accent, for instance, can be signaled by lower, higher or non-expected change in $\mathrm{f}_{0}$. She emphasizes it is necessary to identify pitch accents and intonational boundaries.

The relevant data gathered by the authors mentioned above are complementary and sometimes conflicting but all of them provide support for the occurrence of stress shift in English. Would that be true for Brazilian Portuguese?

\section{LANGUAGE SPECIFIC PROPERTIES: WOULD PORTUGUESE AND ENGLISH BE AFFECTED BY STRESS SHIFT IN THE SAME WAY?}

We consider the differences between Portuguese and English in relation to stress shift productivity should also be worth pondered in relation to more global linguistic features as the direction of the movement of elements in phonological and syntactic 
processes. English favor leftward movements and Portuguese rightward movements despite its trochaic feet which is characteristic of left dominance. Such preferences can be noticed in (relevant elements are presented in boldface):

the structure of noun modification: Portuguese noun phrases exhibit modifiers after the nuclei and only a small number of general adjectives can appear before them. English noun phrases are formed by nouns preceded by modifiers. Some examples of noun phrases in the two languages are: $\{$ an integrated phoneticsphonology approach $\}$ / \{uma abordagem integrada de Fonética-Fonologia\}; \{an expensive navy-blue Chinese silk shirt \} / \{uma saia de seda Chinesa de cor azulmarinho e preço elevado\};

phonological assimilation processes: $\{$ She reads $[\mathrm{z}]$ books $\}$ and $\{$ She writes $[\mathrm{s}]$ books $\}$, but $\{$ Ela faz [s] trabalhos $\}$ and $\{$ Ela faz [z] doces $\}$;

- the productivity of proparoxytons in English and paroxytons in Portuguese: \{cóngruent\} and \{congruénte. BP most frequent lexical stress pattern as pointed out by Albano (1995) is the paroxyton (stress on the penultimate syllable of a word) and the least frequent is the proparoxyton);

- the stress patterns in compounds: \{Whíte Hòuse\}(Casa Bránca) and \{guardachúva\} (umbrella);

passive structures: in English indirect objects and some adverbial adjuncts in the active voice can become subjects in the passive voice but this kind of movement is not allowed in Portuguese: $\{$ She was given a gift $\} /\{$ Deram um presente a ela $\}$; \{The bed had been slept in.\} / \{Haviam dormido na cama. $\}$;

- $\quad \mathrm{f}_{0}$ peak displacement: a strong tendency towards displacement of the $\mathrm{f}_{0}$ peak to the right of the lexically stressed syllables has been found to occur in proparoxytons and oxytons (Madureira et al, 1999). Peak displacement to the right of the syllable bearing the lexical stress is also productive in Spanish (Llisterri et al, 1995), a language whose rhythm is described as syllable timed. The typology of rhythm is also a relevant issue which is discussed in the following item;

- $\quad$ rhythm typology: given stress-timed and syllable-timed kinds of rhythm at the opposite endings in a continuum, English would be closer to the former and BP more distant. Theoretically (Pike, 1945; Abercombrie, 1967), stress-timed languages would have stressed syllables occurring at equivalent time intervals, although no absolute isochrony of stressed-syllables have been found in acoustic studies as Lehiste (1977) points out in a review of the issue. In stressed-timed rhythms there is a tendency towards reduction processes which would be crucial for maintaining the rhythmical beat independent of the number of syllables occurring between the stressed ones. Then, avoiding two adjacent strong stresses 
would be a strategy which would contribute to maintaining the rhythmical beat: \{thírteen Jápanese wómen\}would replace \{thirtéen Japanése wómen\} On the other hand, BP shows a strong tendency to syllable timing when stress groups are smaller than five syllables as it is demonstrated by Barbosa (2000). In a syllabletimed kind of rhythm, syllable duration tends to isochrony and consequently two strong stresses would be according to the perception of the syllables as having approximately the same duration: $\{\mathrm{O}$ Doutór Tomás Críspa $\} /\{\mathrm{O}$ Doutór Thómas Críspa.\}

The raising of the aspects related to language specific features are meant to highlight that English and Portuguese differ as far as the predominance of leftward or rightward dominion in linguistic processes is involved. Perceptually, in English, stress shift is identified and phrases characterized by it are referred as sounding natural. This is not the case for Portuguese. Stress shift in BP both in clash and non-clash conditions can be used to build up speech style by some TV news announcers but its effect strikes as odd. It can also be identified in imitations of English native speakers speaking Portuguese.

Yet some phonological descriptions of BP which follow the metrical Phonology theory incorporate the rhythm reversal rule. However, are there grounds (perceptual and acoustic) to maintain that stress shift apply apart from some stylistic uses?

If no perceptual and acoustic evidence is to be found, how does BP rhythmicality copes with two adjacent strong stresses? The investigation of $\mathrm{f}_{0}$ contours can contribute to finding some evidence that might be helpful to clarify matters.

\section{AN ACOUSTIC EXPERIMENT TO VERIFY PHONETIC EVIDENCES OF STRESS SHIFT IN BRAZILIAN PORTUGUESE: METHODOLOGICAL PROCEDURES}

\subsection{The corpus and recordings}

For the purpose of investigating if there are changes in duration and $\mathrm{f}_{0}$ parameters under clash and non-clash conditions three corpora have been built. The first comprises 21 sentences, the second 10 sentences and the third 15 sentences. The sentences were recorded in studio conditions and presented at random order to three speakers (first and third corpora) who read each of them 5 times and to one speaker 10 times (second corpus).

For the present study we have selected from the corpora six pairs of sentences since they display some differences concerning control effects which are relevant to consider: number of syllables is controlled in sentences $1 \mathrm{a}, 1 \mathrm{~b}, 1 \mathrm{c}$ and $1 \mathrm{~d}$ and the phrases under analysis allow us to consider earlier in relation to later pitch accent placement, but the phonetic context, though similar, is not the same. The phonetic context, the number of syllables and pitch accent placement are completely controlled in sentences $2 a$ and $2 b$. Sentences $3 a$ and $3 b$ do not have the same number of syllables, 
but they allow to compare the occurrence of two strong adjacent stresses under the same syntactic domain.

(1a) Não poderia tomar café frio de novo.

( I would not be able to drink cold coffee again.)

(1b) Não poderia tomar café Pilão de novo.

( I would not be able to drink cold coffee again.)

(1c) Ele e você não tomam café frio de novo.

(He and you won't drink cold coffee again.)

(1d) Ele e você não tomam café Pilão de novo.

(He and you won't drink Pilão coffee again.)

(2 a) Eu comi bolo sexta-feira à noite.

(I ate cake last Friday night)

(2 b) Eu comi bolor sexta-feira à noite.

(I ate mold last Friday night)

(3 a) O canguru dançou samba. ${ }^{2}$

(The kangaroo danced samba)

( 3 b) O canguru australiano dançou samba

(The Australian kangaroo danced samba)

\subsection{Perceptual analysis and measurement procedures}

A perceptual analysis of intonation phrasing was carried out by three phoneticians who identified the kinds of boundaries and prominences to establish the prosodic groups.

The sentences were digitized at $22 \mathrm{kHz}$ using Delta 44 sound board and the software sound forge 4.0 and analyzed at Multi Speech from Kay Elemetrics. The glottal periods were analyzed using default parameters (negative peak; analysis range: 70-300; min peak: 1000) and non-automatic measurement was applied whenever necessary. Wide band spectrograms and formant history tracking were used to identify the limits between the segments as showed in Figure I.

\footnotetext{
${ }^{2}$ Sentences suggested by Dr. Filomena Sandalo from IEL, UNICAMP.
} 


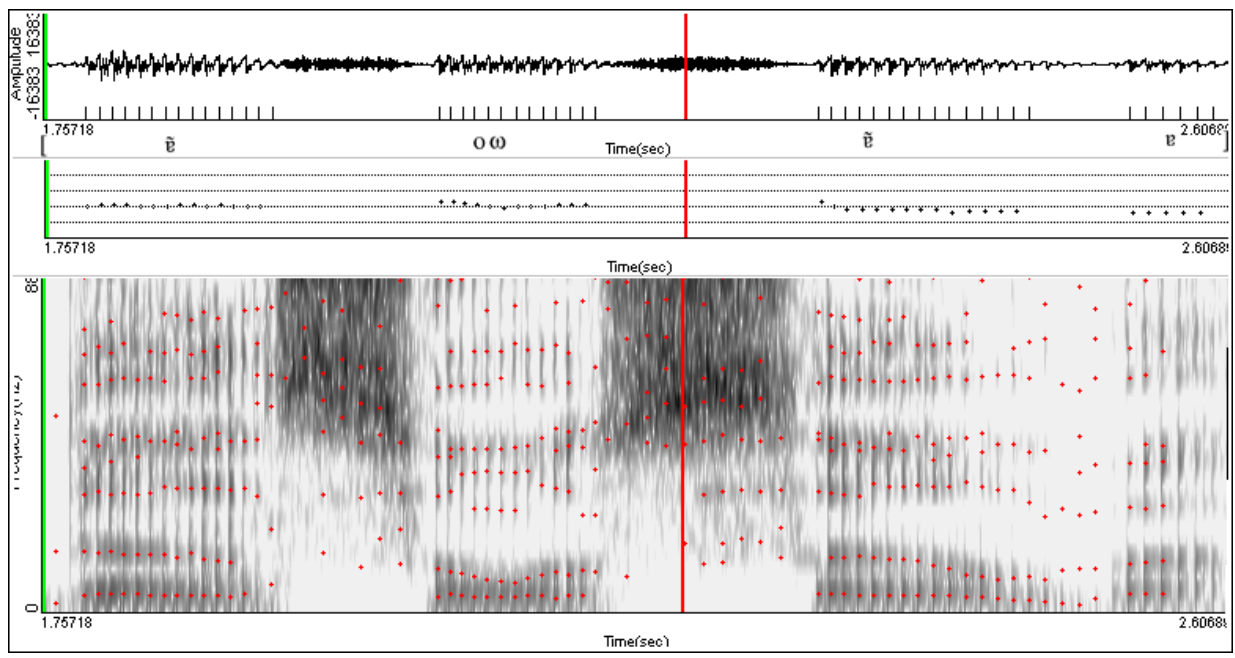

Figure 1: Waveform, pitch contour and wideband spectrogram of one of the repetitions of phrase "dançou samba" by one of the subjects.

For each sentence, besides the specific phonological phrase contours under investigation, the global contours of the sentences were derived.

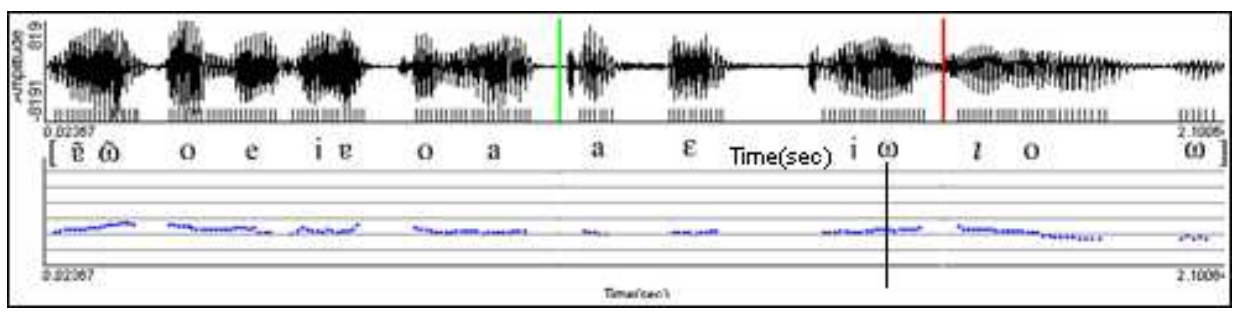

Figure 2: Waveform and global contour of one of the repetitions (subject identified as J.) of the sentence "Não poderia tomar café frio de novo". It demonstrates a rising $\mathrm{f}_{0}$ movement towards the stressed syllable

"fé" takes place and this movement is extended rightwards. The cursor is placed on the syllabic vowel nucleus which bears the peak of $\mathrm{f}_{0}$ in the phrase "café frio". There is $\mathrm{f}_{0}$ peak displacement to the right of the syllable bearing the lexical stress in the word "frio".

Numerical Results (an option at the Analysis Menu) were derived to allow comparison of the evolution of $\mathrm{f}_{0}$ values. When necessary correction was performed manually. For each syllabic nucleus, three $\mathrm{f}_{0}$ average values (across repetitions, and across a given duration, explained below) were taken to represent the beginning, middle and end of the syllable. To obtain these values, averages were calculated taking into account the values occurring at the onset, middle and offset of the syllable nuclei, that is, if $12 f_{0}$ values were extracted for a syllable nucleus, the first four $f_{0}$ values would be taken to provide the average for the onset, and so on, but if 18 values were extracted, the averages would be based on 6 values. The measures were statistically analyzed by means of the SPSS 10.0 for Windows, using Univariat Analysis of Variance, ANOVA, with sentence and syllable as independent factors. Scheffé and Bonferroni were used as 
Post Hoc Tests for Multiple Comparisons. The data for each of the four speakers were analyzed separately. The dependent variable was the mean $f_{0}$ value of the syllable rhymes.

\section{RESULTS AND DISCUSSION}

The perceptual analysis made it possible to identify final boundaries, strong and weak non-final boundaries. Pitch accents, prominences yielded by pitch, were also identified. In the following the symbol $\%$ is used to indicate the presence of final boundaries, the symbol // to indicate the presence of strong, non-final boundaries and the symbol / to indicate weak, non-final boundaries. Words within parenthesis were given prominence.

(1a) Não poderia // tomar café (frio) / de novo \%

(1b) Não poderia // tomar café (Pilão) / de novo \%

(1c) Ele e (você) // não tomam café (frio) / de novo \%

(1d) Ele e (você) // não tomam café (Pilão) / de novo \%

(2 a) Eu comi (bolo) // (sexta-feira) / à noite \%

(2 b) Eu comi (bolor) // (sexta-feira) / à noite \%

(3 a) O (canguru) / dançou (samba) \%

(3 b) $\mathrm{O}$ (canguru) / (australiano) // dançou (samba) \%

In Figure $3 a$ the average $f_{0}$ values of onset, middle and offset of the rhymes of all the repetitions of "tomar café frio" and "tomar café Pilão" in sentences $1 \mathrm{a}$ and $1 \mathrm{~b}$ respectively, are plotted. In Figure $3 \mathrm{~b}$ the average $\mathrm{f}_{0}$ values taken at the middle of the rhymes are given.

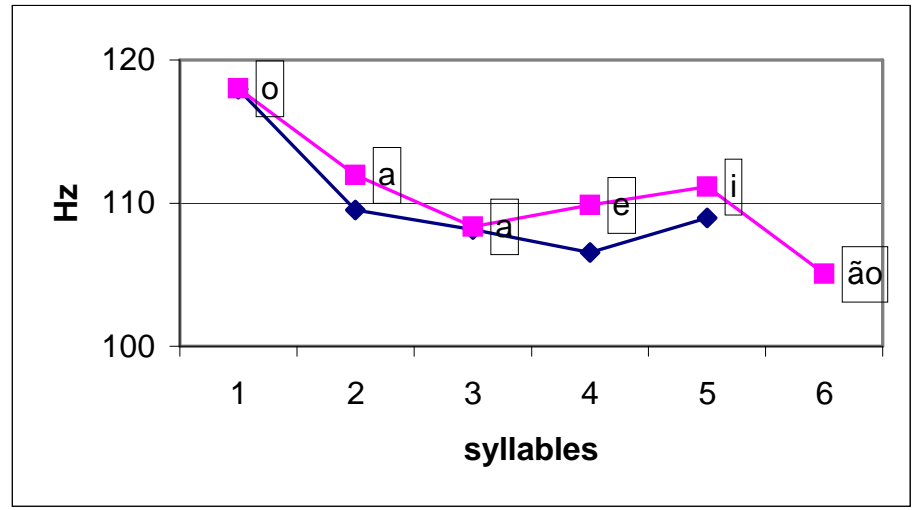

Figure 3a: Evolution of $\mathrm{f}_{0}$ (mean values) in the rhymes of the phonological phrases "tomar café frio" (diamonds) and "tomar café Pilão" (squares) as repeated by the three subjects: averages based on all $\mathrm{f}_{0}$ values in each rhyme. 


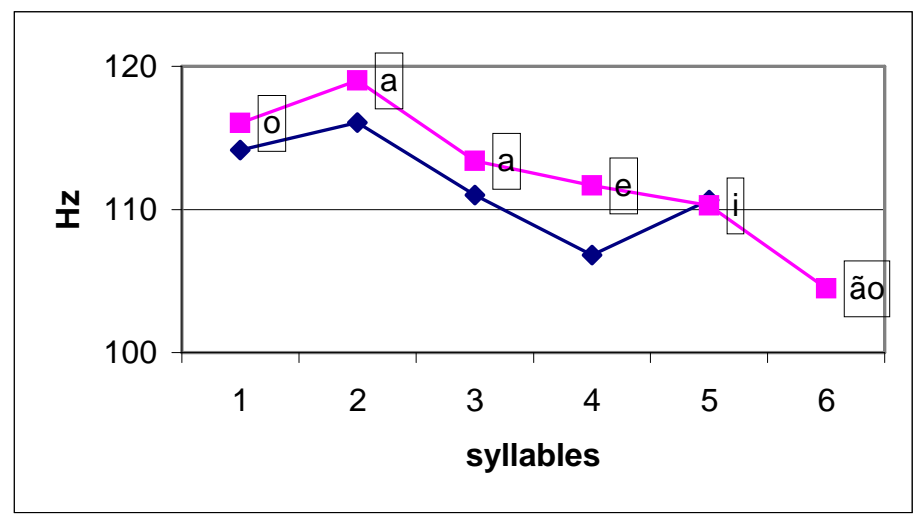

Figure 3b: Evolution of $\mathrm{f}_{0}$ (mean values) in the rhymes of the phonological phrases "tomar café frio" (diamonds) and "tomar café Pilão" (squares) as repeated by the three subjects: averages based on $\mathrm{f}_{0}$ values taken in the middle of the rhymes.

In Figure $4 \mathrm{a}$ the average $\mathrm{f}_{0}$ values of onset, middle and offset of the rhymes of all the repetitions of "tomam café frio" (diamonds) and "tomam café Pilão" (squares) in sentences $1 \mathrm{c}$ and $1 \mathrm{~d}$ are plotted. In Figure $4 \mathrm{~b}$ the average $\mathrm{f}_{0}$ values taken at the middle of the rhymes are given.

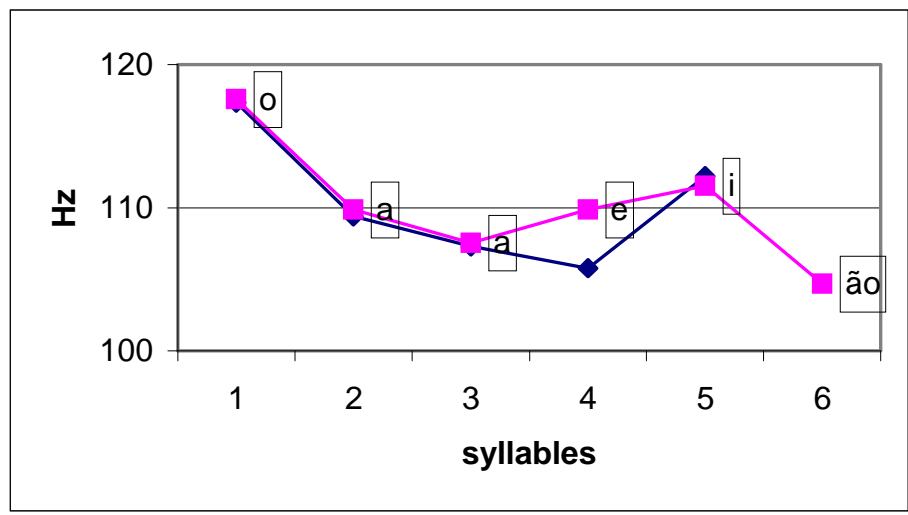

Figure 4a: Evolution of $\mathrm{f}_{0}$ (mean values) in the rhymes of the phonological phrases "tomam café frio" (diamonds) and "tomam café Pilão" (squares) as repeated by the three subjects: averages based on all $\mathrm{f}_{0}$ values in each rhyme. 


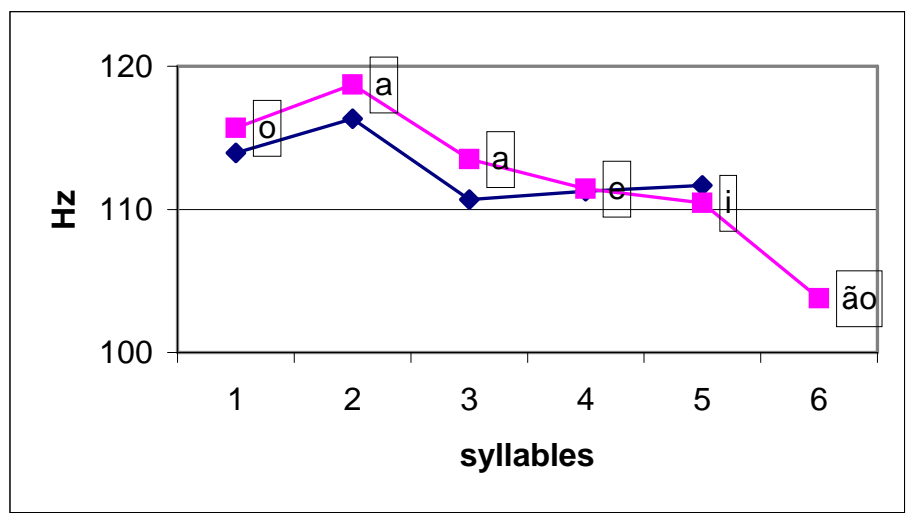

Figure 4b: Evolution of $\mathrm{f}_{0}$ (mean values) in the rhymes of the phonological phrases "tomam café frio" (diamonds) and "tomam café Pilão" (squares) as repeated by the three subjects: averages based on middle $\mathrm{f}_{0}$ values in each rhyme.

In Figures $4 \mathrm{a}$ and $4 \mathrm{~b}, \mathrm{f}_{0}$ movements initiating in the unstressed vowel of "café" culminate at vowel [i]. A rise-fall pattern of pitch from [a] in "café Pilão" and a fall-rise in "café frio" to the most rightward stressed syllable in the phrases occur.

In Figure 5a, the average $\mathrm{f}_{0}$ values of onset, middle and offset of the rhymes of the ten repetitions of the sentences $2 \mathrm{a}$ "Eu comi bolo" and $2 \mathrm{~b}$ "Eu comi bolor" are presented. In Figure $5 b$ average $f_{0}$ values of all the vocalic nuclei, measured at the middle of the rhymes, of the ten repetitions of the same sentences are ploted. Both figures demonstrate values of $\mathrm{f}_{0}$ decrease towards the stressed syllable "mi" and increase towards the stressed syllables "bo" (sentence 2a) and "lor" (sentence 2b). The increasing movement is extended rightwards to the unstressed syllable before the phrase boundary in sentence $2 \mathrm{a}$.

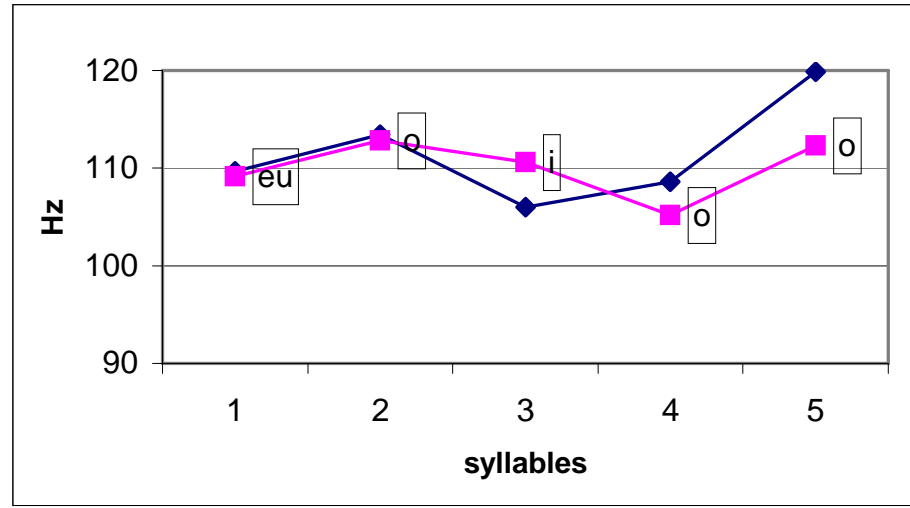

Figure 5a: Evolution of $\mathrm{f}_{0}$ (mean values) in the rhymes of the phonological phrases "Eu comi bolo" (diamonds) and "Eu comi bolor" (squares) as repeated by the only subject who recorded corpus 2: averages based on all $f_{0}$ values in each rhyme. 


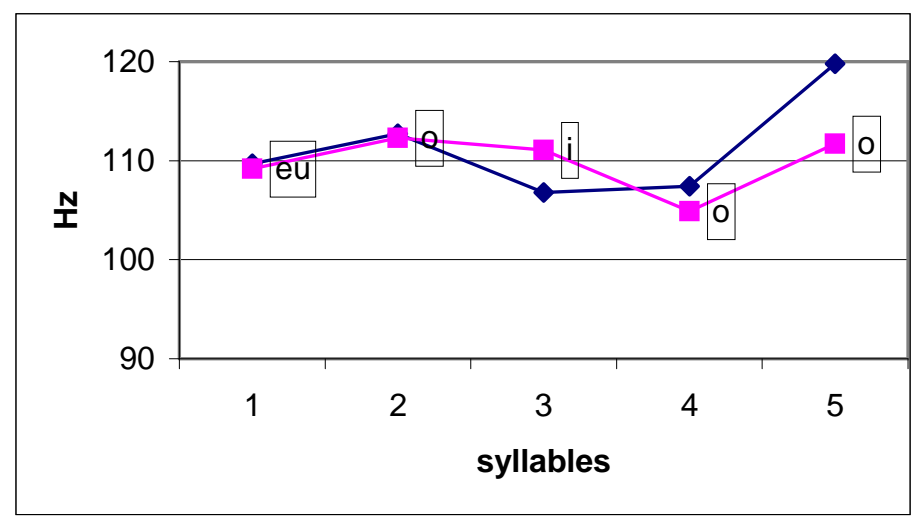

Figure 5b: Evolution of $\mathrm{f}_{0}$ (mean values) in the rhymes of the phonological phrases"Eu comi bolo" (diamonds) and "Eu comi bolor" (squares) as repeated by the only subject who recorded corpus 2: averages based on middle $\mathrm{f}_{0}$ values in each rhyme.

In Figures 5a and 5b, a fall-rise pattern of pitch from [o] in "comi" to the most rightward syllable in the phrases occur.

In Figures 6a and 6b, two instances of the phonological phrase "dançou samba" from sentences $3 \mathrm{a}$ "O canguru dançou samba" and $3 \mathrm{~b}$ "O canguru australiano dançou samba" are contrasted. There is no difference in the direction of $\mathrm{f}_{0}$ movement. The higher values of $\mathrm{f}_{0}$ in the rhyme of the syllable "dan" can be explained by the following: $\mathrm{f}_{0}$ global contour inclination differences (less abrupt in $1 \mathrm{~b}$ which has 5 syllables as many more than 1a), $\mathrm{f}_{0}$ resetting after the strong boundary which follows "australiano", pitch accents placed in "canguru" and "australiano" and $\mathrm{f}_{0}$ movement increasing towards the syllable rightward in the phonological phrase as explained before. The rightward increasing movement extends to "dan" in sentence $3 \mathrm{a}$ and to "aus" in sentence $3 \mathrm{~b}$. After the first stressed syllable before the sentence final boundary in the prosodic group "dançou samba" $\mathrm{f}_{0}$ declines. Fundamental frequency declination in declarative sentences follows linguistic universal trends. 


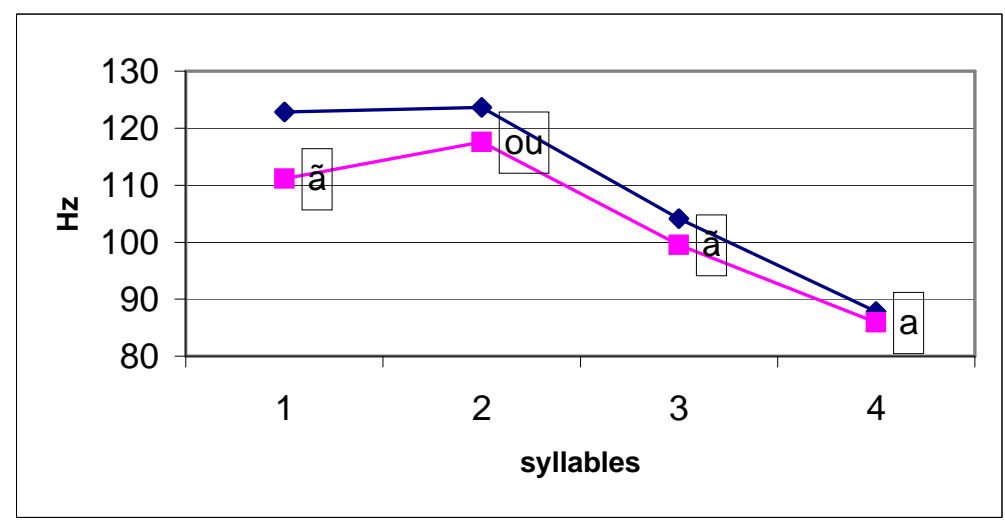

Figure 6a: Evolution of $\mathrm{f}_{0}$ (mean values) in the rhymes of the phonological phrase "dançou samba" as repeated by the tree subjects: averages based on all $\mathrm{f}_{0}$ values in each rhyme. Diamonds refer to the sentence "O canguru dançou samba" and squares to the sentence "O canguru australiano dançou samba".

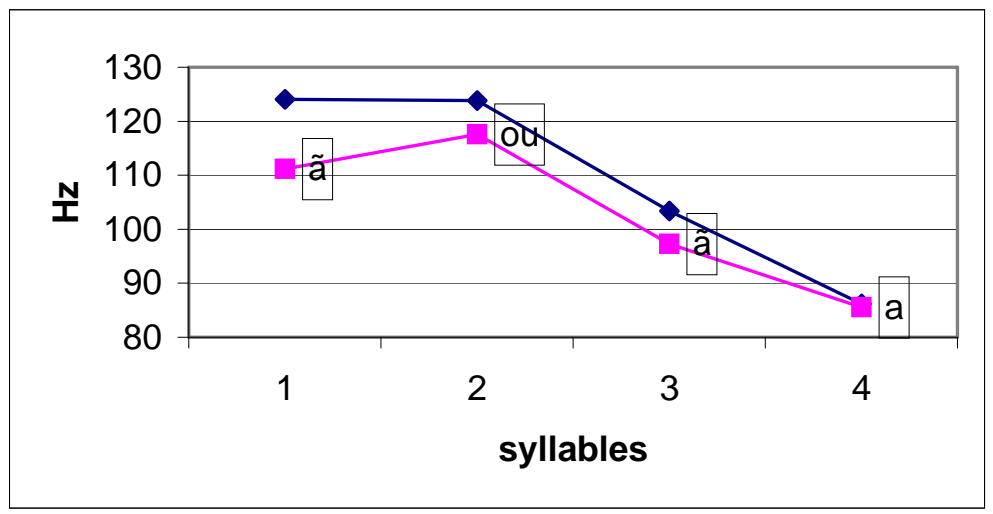

Figure 6b: Evolution of $\mathrm{f}_{0}$ (mean values) in the rhymes of the phonological phrase "dançou samba" as repeated by the three subjects: averages based on middle $\mathrm{f}_{0}$ values in each rhyme. . Diamonds refer to the sentence "O canguru dançou samba" and squares to the sentence "O canguru australiano dançou samba".

Despite the apparent differences, the same pattern can be interpreted to occur in all sentences: $\mathrm{f}_{0}$ movements aim rightward stressed syllable targets in the phonological phrases: either a falling or a rising movement can occur. Rising to a target often 
involves two stages: a preceding falling movement and a rising movement to the stressed rhyme which is usually extended to the syllable at its right side. In sentence $3 \mathrm{a}$ "O canguru dançou samba" $\mathrm{f}_{0}$ rises to the final stressed syllable of canguru and this movement is extended to the following syllable ("dan") in the same way as in "café Pilão" in which $\mathrm{f}_{0}$ increases towards "fé" and this movement is extended to "Pi". In sentence $3 \mathrm{~b}$ "O canguru australiano dançou samba", $\mathrm{f}_{0}$ increases towards the final stressed syllable of "canguru" and it extends to the one that follows it ("aus").

The results (identical in terms of significance of pairs for $\alpha=5 \%$ ) of post hoc tests, Scheffé and Bonferroni, show that there is no significant difference concerning $\mathrm{f}_{0}$ values as adjacent syllables in sentences 1a. 1c. and 3a (clash condition) are compared to adjacent syllables in sentences $1 \mathrm{~b}$. $1 \mathrm{~d}$. and $3 \mathrm{~b}$ (nonclash condition) respectively.

However, sentence $2 \mathrm{a}$ (Eu comi bolo sexta-feira à noite) and sentence $2 \mathrm{~b}$ (Eu comi bolor sexta-feira à noite) are identical regarding $\mathrm{f}_{0}$ evolution from syllable 1 (eu) to syllable 2 (co-) only. In the former, syllable 2 (co-) differs in a significant way from 3 ($\mathrm{mi}$ ), 4 (bo-) and 5 but in the latter, syllable 2 does not differ significantly from syllable 3 and 5 (See Table 1). Such a difference is interpreted as a consequence of having the speaker introduced a perceptually identified pause before the unusual complement of the verb in the sequence "comi bolor" (ate mold). After that pause $\mathrm{f}_{0}$ resets. In Table 1 , mean $\mathrm{f}_{0}$ values, standard deviation values and information about significant differences among syllables are given for all tokens analysed. 
Table 1: $\mathbf{S u}$ stands for subject; $\mathbf{S e}$ for sentence; $\mathbf{S R}$ for syllable taken as reference; $\mathbf{f}_{\mathbf{0}}$ for fundamental frequency; SD for standard deviation and Sds for syllable(s) differing in a significant way $(\mathrm{p}<.05)$ from the syllable taken as reference (SR).

\begin{tabular}{|c|l|l|l|l|c|}
\hline Su & Se & SR & fO Hz & SD & Sds \\
\hline 1 & $1 \mathrm{a}$ & 1 & 110 & $(5)$ & $2 / 3 / 4 / 5$ \\
\hline 1 & $1 \mathrm{a}$ & 2 & 103 & $(4)$ & 1 \\
\hline 1 & $1 \mathrm{a}$ & 3 & 103 & $(6)$ & 1 \\
\hline 1 & $1 \mathrm{a}$ & 4 & 103 & $(3)$ & 1 \\
\hline 1 & $1 \mathrm{a}$ & 5 & 102 & $(8)$ & 1 \\
\hline
\end{tabular}

\begin{tabular}{|l|l|l|l|l|c|}
\hline Su & Se & SR & $\mathbf{f}_{\mathbf{0}} \mathbf{H z}$ & $\mathbf{S D}$ & Sds \\
\hline 2 & $1 \mathrm{a}$ & 1 & 134 & $(13)$ & $3 / 4 / 5$ \\
\hline 2 & $1 \mathrm{a}$ & 2 & 125 & $(10)$ & \\
\hline 2 & $1 \mathrm{a}$ & 3 & 119 & $(10)$ & 1 \\
\hline 2 & $1 \mathrm{a}$ & 4 & 118 & $(8)$ & 1 \\
\hline 2 & $1 \mathrm{a}$ & 5 & 115 & $(6)$ & 1 \\
\hline
\end{tabular}

\begin{tabular}{|l|l|l|l|l|c|}
\hline Su & Se & $\mathbf{S R}$ & $\mathbf{f}_{\mathbf{0}} \mathbf{H z}$ & $\mathbf{S D}$ & Sds \\
\hline 3 & $1 \mathrm{a}$ & 1 & 110 & $(4)$ & $2 / 3 / 4$ \\
\hline 3 & $1 \mathrm{a}$ & 2 & 101 & $(3)$ & $1 / 5$ \\
\hline 3 & $1 \mathrm{a}$ & 3 & 101 & $(4)$ & $1 / 5$ \\
\hline 3 & $1 \mathrm{a}$ & 4 & 99 & $(4)$ & $1 / 5$ \\
\hline 3 & $1 \mathrm{a}$ & 5 & 111 & $(13)$ & $2 / 3 / 4$ \\
\hline
\end{tabular}

\begin{tabular}{|l|l|l|l|l|c|}
\hline Su & Se & SR & $\mathbf{f}_{\mathbf{0}} \mathbf{H z}$ & SD & Sds \\
\hline 1 & $1 \mathrm{~b}$ & 1 & 111 & $(5)$ & $2 / 3 / 4$ \\
\hline 1 & $1 \mathrm{~b}$ & 2 & 103 & $(5)$ & 1 \\
\hline 1 & $1 \mathrm{~b}$ & 3 & 101 & $(6)$ & 1 \\
\hline 1 & $1 \mathrm{~b}$ & 4 & 102 & $(8)$ & 1 \\
\hline 1 & $1 \mathrm{~b}$ & 5 & 108 & $(8)$ & \\
\hline
\end{tabular}

\begin{tabular}{|l|l|l|l|l|c|}
\hline Su & Se & SR & $\mathbf{f}_{\mathbf{0}} \mathbf{H z}$ & $\mathbf{S D}$ & Sds \\
\hline 2 & $1 \mathrm{~b}$ & 1 & 136 & $(9)$ & 3 \\
\hline 2 & $1 \mathrm{~b}$ & 2 & 131 & $(14)$ & \\
\hline 2 & $1 \mathrm{~b}$ & 3 & 124 & $(10)$ & 1 \\
\hline 2 & $1 \mathrm{~b}$ & 4 & 125 & $(7)$ & \\
\hline 2 & $1 \mathrm{~b}$ & 5 & 125 & $(8)$ & \\
\hline
\end{tabular}

\begin{tabular}{|l|l|l|l|l|c|}
\hline Su & Se & $\mathbf{S R}$ & $\mathbf{f}_{\mathbf{0}} \mathbf{H z}$ & $\mathbf{S D}$ & $\mathbf{S d s}$ \\
\hline 3 & $1 \mathrm{~b}$ & 1 & 108 & $(4)$ & $2 / 3 / 4 / 5$ \\
\hline 3 & $1 \mathrm{~b}$ & 2 & 101 & $(2)$ & 1 \\
\hline 3 & $1 \mathrm{~b}$ & 3 & 100 & $(3)$ & 1 \\
\hline 3 & $1 \mathrm{~b}$ & 4 & 102 & $(4)$ & 1 \\
\hline 3 & $1 \mathrm{~b}$ & 5 & 100 & $(3)$ & 1 \\
\hline
\end{tabular}

\begin{tabular}{|l|l|l|l|l|c|}
\hline Su & Se & SR & $\mathbf{f}_{\mathbf{0}} \mathbf{H z}$ & SD & Sds \\
\hline 1 & $1 \mathrm{c}$ & 1 & 111 & $(6)$ & $3 / 4$ \\
\hline 1 & $1 \mathrm{c}$ & 2 & 107 & $(6)$ & 4 \\
\hline 1 & $1 \mathrm{c}$ & 3 & 104 & $(7)$ & 1 \\
\hline 1 & $1 \mathrm{c}$ & 4 & 99 & $(6)$ & $1 / 2$ \\
\hline 1 & $1 \mathrm{c}$ & 5 & 104 & $(6)$ & \\
\hline
\end{tabular}

\begin{tabular}{|l|l|l|l|l|l|}
\hline Su & Se & SR & $\mathbf{f}_{\mathbf{0}} \mathbf{H z}$ & SD & Sds \\
\hline 2 & $1 \mathrm{c}$ & 1 & 128 & $(11)$ & \\
\hline 2 & $1 \mathrm{c}$ & 2 & 136 & $(13)$ & \\
\hline 2 & $1 \mathrm{c}$ & 3 & 127 & $(15)$ & \\
\hline 2 & $1 \mathrm{c}$ & 4 & 118 & $(34)$ & \\
\hline 2 & $1 \mathrm{c}$ & 5 & 123 & $(6)$ & \\
\hline
\end{tabular}

\begin{tabular}{|l|l|l|l|l|l|}
\hline Su & Se & SR & $\mathbf{f}_{\mathbf{0}} \mathbf{H z}$ & SD & Sds \\
\hline 3 & $1 \mathrm{c}$ & 1 & 103 & $(2)$ & \\
\hline 3 & $1 \mathrm{c}$ & 2 & 105 & $(4)$ & \\
\hline 3 & $1 \mathrm{c}$ & 3 & 102 & $(5)$ & \\
\hline 3 & $1 \mathrm{c}$ & 4 & 103 & $(4)$ & \\
\hline 3 & $1 \mathrm{c}$ & 5 & 105 & $(5)$ & \\
\hline
\end{tabular}

\begin{tabular}{|l|l|l|l|l|c|}
\hline Su & Se & SR & $\mathbf{f}_{\mathbf{0}} \mathbf{H z}$ & SD & Sds \\
\hline 1 & $1 \mathrm{~d}$ & 1 & 109 & $(8)$ & 4 \\
\hline 1 & $1 \mathrm{~d}$ & 2 & 108 & $(8)$ & 4 \\
\hline 1 & $1 \mathrm{~d}$ & 3 & 104 & $(8)$ & \\
\hline 1 & $1 \mathrm{~d}$ & 4 & 100 & $(6)$ & $1 / 2$ \\
\hline 1 & $1 \mathrm{~d}$ & 5 & 106 & $(6)$ & \\
\hline
\end{tabular}

\begin{tabular}{|l|l|l|l|l|l|}
\hline Su & Se & SR & $\mathbf{f}_{\mathbf{0}} \mathbf{H z}$ & $\mathbf{S D}$ & Sds \\
\hline 2 & $1 \mathrm{~d}$ & 1 & 135 & $(10)$ & \\
\hline 2 & $1 \mathrm{~d}$ & 2 & 142 & $(14)$ & 5 \\
\hline 2 & $1 \mathrm{~d}$ & 3 & 133 & $(12)$ & \\
\hline 2 & $1 \mathrm{~d}$ & 4 & 132 & $(12)$ & \\
\hline 2 & $1 \mathrm{~d}$ & 5 & 127 & $(9)$ & 2 \\
\hline
\end{tabular}

\begin{tabular}{|l|l|l|l|l|c|}
\hline Su & Se & SR & $\mathbf{f}_{\mathbf{0}} \mathbf{H z}$ & SD & Sds \\
\hline 3 & $1 \mathrm{~d}$ & 1 & 104 & $(2)$ & 5 \\
\hline 3 & $1 \mathrm{~d}$ & 2 & 107 & $(2)$ & $4 / 5$ \\
\hline 3 & $1 \mathrm{~d}$ & 3 & 103 & $(4)$ & $2 / 5$ \\
\hline 3 & $1 \mathrm{~d}$ & 4 & 103 & $(3)$ & $2 / 5$ \\
\hline 3 & $1 \mathrm{~d}$ & 5 & 98 & $(4)$ & $1 / 2 / 3 / 4$ \\
\hline
\end{tabular}

\begin{tabular}{|l|l|l|l|l|c|}
\hline Su & Se & SR & $\mathbf{f}_{\mathbf{0}} \mathbf{H z}$ & $\mathbf{S D}$ & $\mathbf{S d s}$ \\
\hline 1 & $2 \mathrm{a}$ & 1 & 110 & $(3)$ & 5 \\
\hline 1 & $2 \mathrm{a}$ & 2 & 113 & $(4)$ & $3 / 4 / 5$ \\
\hline 1 & $2 \mathrm{a}$ & 3 & 107 & $(4)$ & 5 \\
\hline 1 & $2 \mathrm{a}$ & 4 & 107 & $(5)$ & $2 / 5$ \\
\hline 1 & $2 \mathrm{a}$ & 5 & 120 & $(3)$ & $\begin{array}{c}1 / 2 / 3 / \\
4\end{array}$ \\
\hline
\end{tabular}

\begin{tabular}{|l|l|l|l|l|c|}
\hline Su & Se & SR & $\mathbf{f}_{0} \mathbf{H z}$ & SD & Sds \\
\hline 1 & $2 b$ & 1 & 109 & $(3)$ & \\
\hline 1 & $2 b$ & 2 & 112 & $(3)$ & 4 \\
\hline 1 & $2 b$ & 3 & 111 & $(3)$ & 4 \\
\hline 1 & $2 b$ & 4 & 105 & $(2)$ & $2 / 3 / 5$ \\
\hline 1 & $2 b$ & 5 & 112 & $(7)$ & 4 \\
\hline
\end{tabular}




\begin{tabular}{|l|l|l|l|l|l|}
\hline Su & Se & SR & $\mathbf{f}_{\mathbf{0}} \mathbf{H z}$ & $\mathbf{S D}$ & $\mathbf{S d s}$ \\
\hline 1 & $3 \mathrm{a}$ & 1 & 116 & $(1)$ & $3 / 4$ \\
\hline 1 & $3 \mathrm{a}$ & 2 & 114 & $(4)$ & $3 / 4$ \\
\hline 1 & $3 \mathrm{a}$ & 3 & 93 & $\square$ & $1 / 2 / 4$ \\
\hline 1 & $3 \mathrm{a}$ & 4 & 85 & $(5)$ & $1 / 2 / 3$ \\
\hline
\end{tabular}

\begin{tabular}{|l|l|l|l|l|c|}
\hline Su & Se & SR & $\mathbf{f}_{\mathbf{0}} \mathbf{H z}$ & SD & Sds \\
\hline 2 & $3 \mathrm{a}$ & 1 & 143 & $(5)$ & 4 \\
\hline 2 & $3 \mathrm{a}$ & 2 & 148 & $(7)$ & $3 / 4$ \\
\hline 2 & $3 \mathrm{a}$ & 3 & 129 & $(9)$ & $2 / 4$ \\
\hline 2 & $3 \mathrm{a}$ & 4 & 96 & $(6)$ & $1 / 2 / 3$ \\
\hline
\end{tabular}

\begin{tabular}{|l|l|l|l|l|c|}
\hline Su & Se & SR & $\mathbf{f}_{\mathbf{0}} \mathbf{H z}$ & SD & Sds \\
\hline 3 & $3 \mathrm{a}$ & 1 & 113 & $(3)$ & $3 / 4$ \\
\hline 3 & $3 \mathrm{a}$ & 2 & 110 & $(3)$ & $3 / 4$ \\
\hline 3 & $3 \mathrm{a}$ & 3 & 88 & $(5)$ & $1 / 2 / 4$ \\
\hline 3 & $3 \mathrm{a}$ & 4 & 77 & $(2)$ & $1 / 2 / 3$ \\
\hline
\end{tabular}

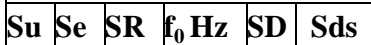

\begin{tabular}{|l|l|l|l|l|c|}
\hline 1 & $3 \mathrm{~b}$ & 1 & 105 & $(1)$ & $3 / 4$ \\
\hline 1 & $3 \mathrm{~b}$ & 2 & 107 & $(5)$ & $3 / 4$ \\
\hline 1 & $3 \mathrm{~b}$ & 3 & 92 & $(1)$ & $1 / 2 / 4$ \\
\hline 1 & $3 \mathrm{~b}$ & 4 & 85 & $(3)$ & $1 / 2 / 3$ \\
\hline
\end{tabular}

\begin{tabular}{|l|l|l|l|l|c|}
\hline Su & Se & SR & $\mathbf{f}_{\mathbf{0}} \mathbf{H z}$ & SD & Sds \\
\hline 2 & $3 b$ & 1 & 127 & $(7)$ & 4 \\
\hline 2 & $3 b$ & 2 & 137 & $(7)$ & $3 / 4$ \\
\hline 2 & $3 b$ & 3 & 117 & $(11)$ & $2 / 4$ \\
\hline 2 & $3 b$ & 4 & 96 & $(10)$ & $1 / 2 / 3$ \\
\hline
\end{tabular}

\begin{tabular}{|l|l|l|l|l|l|}
\hline Su & Se & SR & $\mathbf{f}_{\mathbf{0}} \mathbf{H z}$ & SD & Sds \\
\hline 3 & $3 b$ & 1 & 102 & $(5)$ & $3 / 4$ \\
\hline 3 & $3 b$ & 2 & 109 & $(5)$ & $3 / 4$ \\
\hline 3 & $3 b$ & 3 & 83 & $(4)$ & $1 / 2$ \\
\hline 3 & $3 b$ & 4 & 76 & $(2)$ & $1 / 2$ \\
\hline
\end{tabular}

We can conclude from the analysis of the corpora that the stress clash condition had no effect on changing fo patterns. The only significant difference concerning $\mathrm{f}_{0}$ values is related to changes in prosodic grouping which yield different pitch accent placements. Barbosa (this volume) shows duration increases towards the syllable which bears the phrasal stress. Our investigation of $\mathrm{f}_{0}$ contours in prosodic phrases complements his finding since phrasal stresses are targets for peak placement and changes in fundamental frequency values as described in this section of the paper are necessary to implement them.

\section{CONCLUSION}

Our position is that stress shift in BP is an optional phenomenon which operates independently of clash and non-clash conditions and can also be motivated by stylistic reasons. The results of our experiment lead us to raise a hypothesis that stress shift productivity in languages, dialects or oral styles may be related to the strength of the tendency to stress or syllable timing. A strong tendency to stress timing would determine the use of mechanisms to avoid the adjacency of two strong stresses or reduction of one of them, while a strong tendency towards syllable timing would not require so. This hypothesis has implications for the proposal of an integrated model of rhythm and intonation as proposed by Barbosa (this volume).

ACKNOWLEDGMENTS This work was partially financed by a grant from a FAPESP project number 01/00136-2: "Integrating Continuity and Discreteness in Modeling Phonic and Lexical Knowledge". Thanks to Plínio Almeida Barbosa for his contribution, to the speakers Antonio Carlos Silva Júnior, Jefferson dos Santos and Maurício Alexandre Souza Campos for their voices, and to Ernesto Luís Foschi, Yara Castro, Fernanda Rocha Cuzinatto, Mário A. S. Fontes and Mário Fontes for providing academic and technical support. 


\section{REFERENCES}

ABERCOMBRIE, D. (1967) Elements of General Phonetics. Edinburgh: Edinburgh University Press.

ALBANO, E.C. (1999) Gestural solutions for some glide epenthesis problems. Proceedings of the XIVth International Congress of Phonetic Sciences. August 1-7, San Francisco, USA, v.3, 2211-2214. (2001) O Gesto e suas Bordas: Esboço de Fonologia Acústico-Articulatória do Português Brasileiro. Mercado de Letras: Campinas, Brazil.

ALBANO, E.C., MOREIRA, A., AQUINO, P., SILVA, A. \& KAKINOHARA, R. (1995) Segment frequency and word structure in Brazilian Portuguese. Proceedings of the XII ${ }^{\text {th }}$ International Congress of Phonetic Sciences. August 13- 20, Stockholm, Sweden, vol.3, 346-349.

ARANTES, P. \& BARBOSA, P. A. (forthcoming) Acentuação secundária em português brasileiro à luz de um modelo dinâmico do ritmo: um estudo-piloto. Anais do I Congresso Internacional Fonética e Fonologia/VII Congresso Nacional e Fonética e Fonologia. 28-30 de outubro de 2002. Belo Horizonte.

BARBOSA, P.A. (1996) At least two macrorhythmic units are necessary for modeling Brazilian Portuguese duration: emphasis on segmental duration generation. Cadernos de Estudos Lingüísticos, 31, 33-53. . (2000) "Syllable-Timing in Brazilian Portuguese": uma Crítica a Roy Major. D.E.L.T.A., 16 (2), $369-402$.

BARBOSA, P.A. \& MADUREIRA, S. (1999) Toward a hierarchical model of rhythm production: evidence from phrase stress domains in Brazilian Portuguese. Proceedings of the XIV ${ }^{\text {th }}$ International Congress of Phonetic Sciences, 1, 297-300.

BECKMAN, M.E. \& EDWARDS J. (1994) Articulatory evidence for differentiating stress categories. In: Keating, P. A. (ed) Phonological Structures and Phonetic Form: Papers in Language Laboratory III. Cambridge: Cambridge University Press.

BROWMAN, C.P. \& GOLDSTEIN, L. (1986) Towards an articulatory phonology. Phonology Yearbook, 3, 219-252.

. (1989) Articulatory Gestures as Phonological Units. Phonology, 6, 201-251.

(1990) Tiers in Articulatory Phonology with some Implications for Casual Speech. In Papers in Laboratory Phonology I, Kingston, J. and BECKMAN, M. E. (eds). Cambridge: Cambridge University Press, 341-376.

GALVES, C. \& ABAURRE, M.B. (1996) Os Clíticos no Português Brasileiro: Elementos para uma Abordagem Sintático-Fonológica. In Castilho, A. T. and Basílio, M (orgs) Gramática do Português Falado: Estudos Descritivos. Campinas: Editora da Unicamp/Fapesp.

GAMA-ROSSI, A. (1998) Qual é a natureza do acento secundário no português brasileiro? Cadernos Cenro Universitário São Camilo 4 (1), 77-92.

GRABE, E. \& WARREN, P. Stress Shift: do speakers do it or do listeners hear it? In: Connell, B. \& Arvaniti, A. (Eds.) (1995) Phonology and Phonetic Evidence: Papers in Laboratory Phonology IV. Cambridge: Cambridge University Press, 95-110.

LEHISTE, I. (1977) Isochrony reconsidered. Journal of Phonetics, 5, 253-263.

LIBERMAN, M. \& PRINCE, A. (1977) On stress and linguistic rhythm. Linguistic Inquiry 8 (2), 249-336. 
LLISTERRI, J. MARIN, R., MOTA, C. and RIOS A (1995) Factors affecting f0 peak displacement in Spanish. Proceedings of the $4^{\text {th }}$ European Conference on Speech Communication and Technology. Madrid, 2061- 2064.

MADUREIRA, S.; BARBOSA, P.A.; FONTES, M.; CRISPIM, K., \& SPINA, D. (1999) Post-stressed Syllables in Brazilian Portuguese as Markers. Proceedings of ICPhS 99, San Francisco, vol.2, p. 917920.

MORAES, J.A. (1998) Intonation in Brazilian Portuguese. In: Hirst, D. and A. Di Cristo (eds.) Intonation Systems.Cambridge University Press

MASSINI, G. (1991) A Duração no estudo do acento e do ritmo em português. Master's thesis. Campinas: University of Campinas.

MONAGHAN, A.I.C. (1990) Rhythm and stress-shift in speech synthesis. Computer Speech and Language, 471-78.

PIKE, K.L. (1945) The intonation of American English. Ann Arbor: University of Michigan Press.

SHATTUCK-HUFNAGEL, S. (1988) Acoustic correlates of stress shift. Journal of the Acoustic Society of America, 84:S98.

. (1995) The importance of prosodic transcription in empirical approaches to "stress shift" versus "early accent": comments on Grabe and Warren, and Vogel, Bunnell and Hoskins. In: Connell, B. and Arvaniti, A. (Eds.) Phonology and Phonetic Evidence: Papers in Laboratory Phonology IV. Cambridge: Cambridge University Press, 128-140.

SHATTUCK-HUFNAGEL, S., OSTENDORF, M. \& ROSS, K. (1994) Stress shift and early pitch accent placement in lexical items in American English. Journal of Phonetics 22, 357-388.

VOGEL, I., BUNNEL, H.T. \& HOSKINS, S. (1995) The phonology and phonetics of the Rhythm Rule. In: Connell, B. and Arvaniti, A. (Eds.) Phonology and Phonetic Evidence: Papers in Laboratory Phonology IV. Cambridge: Cambridge University Press, $111-127$. 